\title{
A Novel Trp-rich Model Antimicrobial Peptoid with Increased Protease Stability
}

\author{
Jeong-Kyu Bang, ${ }^{\dagger}$ Yong Hai Nan, Eun Kyu Lee, and Song Yub Shin* \\ Department of Bio-Materials, Graduate School, and Department of Cellular \& Molecular Medicine, School of Medicine, \\ Chosun University, Gwangju 501-759, Korea.*E-mail: syshin@chosun.ac.kr \\ ${ }^{\dagger}$ Division of Magnetic Resonance, Korea Basic Science Institute, 804-1 Yangchung-ri, Ochang, Chungbuk 363-883, Korea \\ Received July 1, 2010, Accepted July 12, 2010
}

\begin{abstract}
In order to increase protease stability of a novel Trp-rich model antimicrobial peptide, $\mathrm{K}_{6} \mathrm{~L}_{2} \mathrm{~W}_{3}$ (KLWKKWKKWLK$\mathrm{NH}_{2}$ ) and investigate the effect of $\mathrm{L}$-amino acid to peptoid residue conversion on biological functions, we synthesized its antimicrobial peptoid, $\mathrm{k}_{6} \mathrm{l}_{2} \mathrm{~W}_{3}$. Peptoid $\mathrm{k}_{6} \mathrm{l}_{2} \mathrm{~W}_{3}$ had similar bacterial selectivity compared to peptide $\mathrm{K}_{6} \mathrm{~L}_{2} \mathrm{~W}_{3}$. The bactericidal rate of $\mathrm{k}_{6} \mathrm{l}_{2} \mathrm{~W}_{3}$ was somewhat slower than that of $\mathrm{K}_{6} \mathrm{~L}_{2} \mathrm{~W}_{3}$. Peptoid $\mathrm{k}_{6} \mathrm{l}_{2} \mathrm{~W}_{3}$ exhibited very little dye leakage from bacterial outer-membrane mimicking PE/PG liposomes, as observed in $\mathrm{K}_{6} \mathrm{~L}_{2} \mathrm{~W}_{3}$, indicating that the major target site of $\mathrm{K}_{6} \mathrm{~L}_{2} \mathrm{~W}_{3}$ and $\mathrm{k}_{6} \mathrm{l}_{2} \mathrm{~W}_{3}$ may be not the cell membrane but the cytoplasm of bacteria. Trypsin treatment of $\mathrm{K}_{6} \mathrm{~L}_{2} \mathrm{~W}_{3}$ completely abolished antimicrobial activities against Escherichia coli and Staphylococcus aureus. In contrast, the antimicrobial activity of $\mathrm{k}_{6} \mathrm{l}_{2} \mathrm{~W}_{3}$ was completely preserved after trypsin treatment. Taken together, our results suggested that antimicrobial peptoid $\mathrm{k}_{6} \mathrm{l}_{2} \mathrm{~W}_{3}$ can potentially serves as a promising therapeutic agent for the treatment of microbial infection.
\end{abstract}

Key Words: Peptoid, Protease stability, Trp-rich model antimicrobial peptide

\section{Introduction}

Antimicrobial peptides (AMPs) are produced in a wide variety of organisms and represent key components of the innate immune system, providing a fast acting weapon against invading pathogens including bacteria, fungi, and yeast. ${ }^{1-4}$ They have emerged as a potential new class of antimicrobial agents with new modes of actions. ${ }^{5}$ There are AMPs which are rich in a certain specific amino acid such as Pro, Trp, or Arg. ${ }^{6}$ The amino acid Trp is of particular interest with regard to the partitioning of peptides into lipid membranes because of its propensity to position itself near the membrane/water interface. ${ }^{7,8}$ Due to these important features of Trp residues in peptide-membrane interaction, the structure and mechanism of action of Trp-rich AMPs such as indolicidin and tritrpticin have been studied recently. ${ }^{7-10}$ Although indolicidin and tritrpticin display potent antibiotic activity against a wide range of targets, including Gram-positive and Gram-negative bacteria, fungi, protozoa and some virus, their relative high toxicity against human erythrocytes and normal mammalian cells prevents their therapeutic application as antimicrobial agents. ${ }^{9-13}$

In the previous study, we developed a novel short Trp-rich model antimicrobial peptide, $\mathrm{K}_{6} \mathrm{~L}_{2} \mathrm{~W}_{3}$ (KLWKKWKKWLK$\mathrm{NH}_{2}$ ) with much higher bacterial selectivity than the naturallyoccurring Trp-rich AMP, indolicidin. ${ }^{14}$ This peptide showed a potent antimicrobial activity with MIC ranging between $2 \mu \mathrm{M}$ to $8 \mu \mathrm{M}$, but no hemolytic activity even at concentration of $400 \mu \mathrm{M}^{14}$

A major limitation of antimicrobial peptides is inactivation by endogenous proteases. Poor protease stability severely limits the clinical use of many therapeutic peptides composed L-amino acids. ${ }^{15-18}$ Also, $\mathrm{K}_{6} \mathrm{~L}_{2} \mathrm{~W}_{3}$ can easily inactivated by the protease such as trypsin.

Peptoid ( $N$-alkylglycyl) residues are imino acids because their side chains are shifted from the $\alpha$-carbon position to the
N-position. Peptoids generally exhibit greater proteolytic stability and bioavailability than their respective peptides. ${ }^{19}$ Peptoids have been found to be potential drugs as discovered from peptidomimetic libraries ${ }^{20}$ and determined to be effective molecular transporters via their enhancement of the cellular uptake of agents. ${ }^{21}$ In another interesting application, Leu peptoid residues (Nleu) has been introduced as a substituted proline into synthetic collagen-like structures. ${ }^{22}$

In this study, to increase the stability of $\mathrm{K}_{6} \mathrm{~L}_{2} \mathrm{~W}_{3}$ to the protease and investigate the effect of L-amino acid to peptoid residue conversion on biological functions, we synthesized the antimicrobial peptoid, $\mathrm{k}_{6} \mathrm{l}_{2} \mathrm{~W}_{3}$ (klwkkwkkwlk- $\mathrm{NH}_{2}$ ) to $\mathrm{K}_{6} \mathrm{~L}_{2} \mathrm{~W}_{3}$. Cell selectivity of the peptides was investigated by assessing their antimicrobial activity against gram-positive and gramnegative bacterial strains and their hemolytic activity against human red blood cells. To gain insight into the mechanism of bactericidal action of the peptides, we examined the leakage of calcein from PE/PG (7:3, w/w) liposomes which mimic the outer leaflet of the plasma membrane of bacteria. Furthermore, in order to assess the potential of $\mathrm{k}_{6} \mathrm{l}_{2} \mathrm{~W}_{3}$ as a therapeutic antimicrobial agent, its stability toward tryptic digestion was examined.

\section{Materials and Methods}

Materials. Rink amide 4-methylbenzhydrylamine (MBHA) resin and 9-fluorenylmethoxycarbonyl (Fmoc) amino acids were obtained from Calbiochem-Novabiochem (La Jolla, CA). Other reagents used for peptide synthesis included trifluoroacetic acid (TFA; Sigma), piperidine (Merck), dicyclohexylcarbodiimide (DCC; Fluka), $N$-hydroxybenzotriazole hydrate (HOBT; Aldrich) and dimethylformamide (DMF, peptide synthesis grade; Biolab). Phosphatidylcholine (PC, from egg yolk), phosphatidylethanolamine (PE, from egg yolk), phosphatidylglycerol (PG, from egg yolk), cholesterol, calcein and trypsin (from 
(a)

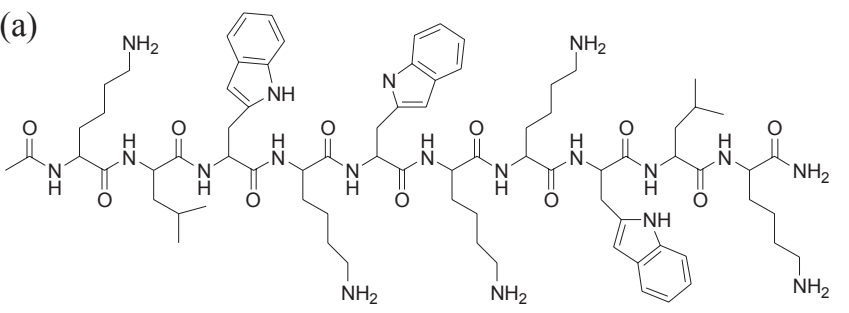

(b)

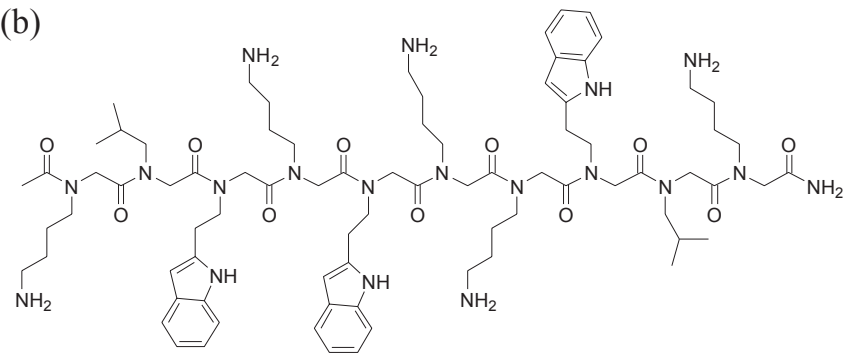

Figure 1. Chemical structure of peptide $\mathrm{K}_{6} \mathrm{~L}_{2} \mathrm{~W}_{3}$ (a) and peptoid $\mathrm{k}_{6} \mathrm{l}_{2} \mathrm{~W}_{3}(\mathrm{~b})$.

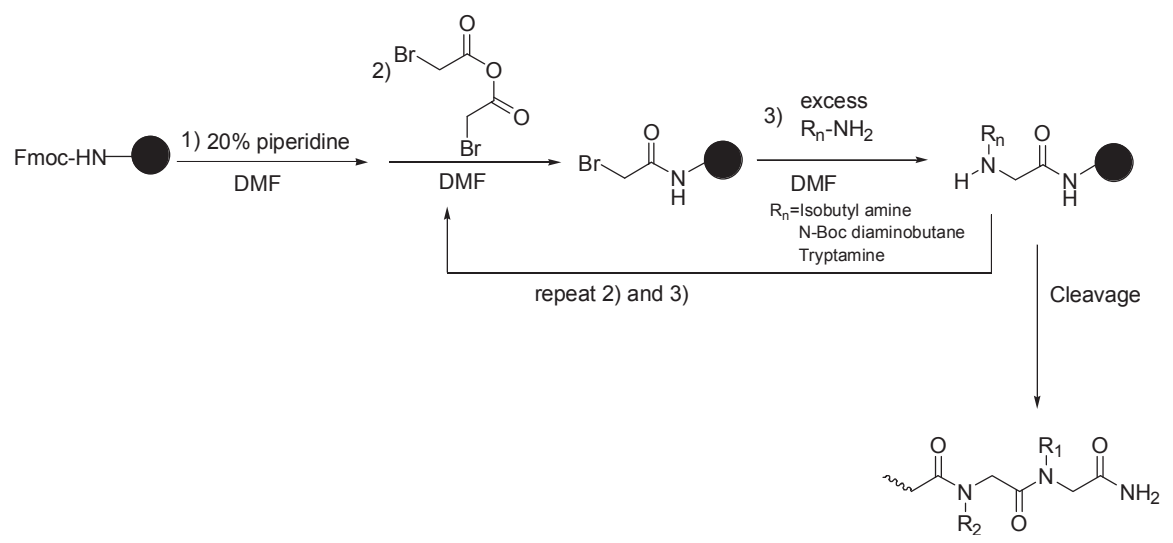

Figure 2. Synthetic scheme of peptoid $\mathrm{k}_{6} \mathrm{l}_{2} \mathrm{~W}_{3}$.

bovine pancreas, EC 3.4.21.4) were purchased from Sigma Chemical Co (St. Louis, MO). All other reagents were of analytical grade. The buffers were prepared in double glass-distilled water.

Peptide synthesis. The peptide $\mathrm{K}_{6} \mathrm{~L}_{2} \mathrm{~W}_{3}$ shown in Figure 1-a were synthesized by the standard Fmoc-based solid-phase method ${ }^{23,24}$ on rink amide MBHA resin $(0.54 \mathrm{mmole} / \mathrm{g})$. DCC (dicyclohexylcarbodiimide) and $\mathrm{HOBt}$ (N-hydroxybenzotriazole) were used as coupling reagent, and ten-fold excess Fmocamino acids were added during every coupling cycle. After cleavage and deprotection with a mixture of trifluoroacetic acid/ water/thioanisole/phenol/ethanedithiol/triisopropylsilane $(81.5: 5: 5: 5: 2.5: 1, \mathrm{v} / \mathrm{v} / \mathrm{v} / \mathrm{v} / \mathrm{v} / \mathrm{v})$ for $2 \mathrm{~h}$ at room temperature, the crude peptide was repeatedly extracted with diethyl ether and purified by reverse phase HPLC on a preparative Vydac $\mathrm{C}_{18}$ column $(15 \mu \mathrm{m}, 20 \times 250 \mathrm{~mm})$ using an appropriate $0-90 \%$ water/acetonitrile gradient in the presence of $0.05 \%$ trifluoroacetic acid. The final purity of the peptides $(>98 \%)$ was assessed by reverse phase HPLC on an analytical Vydac $\mathrm{C}_{18}$ column (4.6 mm $\times 250 \mathrm{~mm}, 300 \AA$, 5- $\mu \mathrm{m}$ particle size).

Peptoid synthesis. The peptoid $\mathrm{k}_{6} \mathrm{l}_{2} \mathrm{~W}_{3}$ shown in Figure 1-b was synthesized manually using a modification of the submonomer method (Figure 2). ${ }^{25}$ Rink Amide AM resin (100mg, $0.061 \mathrm{mmol}, 1$ equiv.) was added to a fritted polypropylene tube followed by DMF ( $5 \mathrm{~mL}$ ), and was swelled for $20 \mathrm{~min}$ with agitation. Next, the Fmoc protecting group was removed by treatment with $20 \%$ piperdine $(2 \mathrm{~mL}$ ) in DMF for $15 \mathrm{~min}$. The resin was washed with DMF. Then, the amine on solid phase was bromoacetylated with $0.6 \mathrm{M}$ solution of bromoacetic anhydride in DMF ( $1 \mathrm{~mL}, 0.6 \mathrm{mmol}, 10$ equiv.). The reaction was
Table 1. Amino acid sequences and calculated and observed molecular masses of a Trp-rich model antimicrobial peptide and peptoid

\begin{tabular}{llcc}
\hline \multirow{2}{*}{ Peptides } & \multirow{2}{*}{ Amino acid sequences } & \multicolumn{2}{c}{ Molecular MS } \\
\cline { 3 - 4 } & & Calculated & Measured $^{a}$ \\
\hline $\mathrm{K}_{6} \mathrm{~L}_{2} \mathrm{~W}_{3}$ & KLWKKWKKWLK-NH & 1571.0 & 1570.4 \\
$\mathrm{k}_{6} \mathrm{l}_{2} \mathrm{~W}_{3}$ & klwkkwkkwlk-NH & 1613.0 & 1612.7
\end{tabular}

Small letters represent peptiod residues. k: $N$ Lys [ $N$-aminobutylglycine], 1: $N$ leu [N-isobutylglycine], w: $N$ htrp [ $N$-(3-indolylethyl)glycine] ${ }^{a}$ Molecular masses of the peptides were determined by MALDI-TOF MS.

agitated for $90 \mathrm{~min}$ at room temperature. This acylation step was repeated once. The resin was rinsed with DMF to remove excess reagent. Then, displacement reactions were performed by addition of appropriate primary amine [1.2 mmol, 20 equiv. Isobutylamine for Nleu (Leu peptoid residue), Tryptamine for Nhtrp (Trp peptoid residue), N-Boc diaminobutane for Nlys (Lys peptoid residue)] as 1.5 M solution in DMF, followed by agitated for $3 \mathrm{~h}$ at room temperature. The resin was washed with DMF to remove excess reagent. Peptoid was elongated by successive repetition of the above two steps until the desired sequence was obtained. After, deprotection and purification of crude peptoid were performed as described in the section of peptide synthesis. The molecular mass of purified peptide and peptoid was determined by MALDI-TOF MS (matrix-assisted laser desorption/ionization time-of-flight mass spectrometry) (Shimadzu, Japan) (Table 1).

Bacterial strains. Three types of gram-positive bacteria (Bacillus subtilis [KCTC 3068], Staphylococcus epidermidis [KCTC 1917] and Staphylococcus aureus [KCTC 1621]) and 3 
types of gram-negative bacteria (Escherichia coli [KCTC 1682], Pseudomonas aeruginosa [KCTC 1637] and Salmonella typhimurium [KCTC 1926]) were procured from the Korean Collection for Type Cultures (KCTC) at the Korea Research Institute of Bioscience and Biotechnology (KRIBB).

Antimicrobial activity and kinetics of killing. The antimicrobial activity of the peptides against 3 gram-positive bacterial strains and 3 gram-negative bacterial strains was examined by using the broth microdilution method. ${ }^{26-29}$ To determine the salt sensitivity of the antimicrobial activity, the peptides were incubated at $37{ }^{\circ} \mathrm{C}$ in $200 \mu \mathrm{L}$ of $1 \%$ peptone solution also containing $2 \times 10^{6}$ colony-forming units $(\mathrm{CFU}) / \mathrm{mL}$. After incubation for $18-20 \mathrm{~h}$ at $37{ }^{\circ} \mathrm{C}$, bacterial growth inhibition was determined by measuring the absorbance at $600 \mathrm{~nm}$ with a Microplate autoreader EL 800 (Bio-Tek Instruments, VT). The minimal inhibitory concentration (MIC) was defined as the minimum peptide concentration inhibited bacteria growth.

The kinetics of antimicrobial activity against gram-negative E. coli (KCTC 1682) and gram-positive S. aureus (KCTC 1621) of the peptides was assessed at a peptide concentration of 16.0 $\mu \mathrm{M}$. The initial density of $E$. coli or $S$. aureus was approximately $2 \times 10^{6} \mathrm{CFU} / \mathrm{ml}$. After $0,10,30$, or $60 \mathrm{~min}$ of exposure to the peptides at $37^{\circ} \mathrm{C}, 50 \mu \mathrm{L}$ aliquots of serial 10 -fold dilutions (up to $10^{-3}$ ) of the cultures were plated onto LB agar plates to assess their viability. Colonies were counted after incubation for 24 $\mathrm{h}$ at $37^{\circ} \mathrm{C}$. The results of two independent experiments were averaged.

Hemolytic activity. Fresh human red blood cells (hRBCs) were washed 3 times with PBS ( $35 \mathrm{mM}$ phosphate buffer, 0.15 $\mathrm{M} \mathrm{NaCl}, \mathrm{pH} 7.4$ ) by centrifugation for $7 \mathrm{~min}$ at $1000 \times \mathrm{g}$, and resuspended in PBS. The peptide solutions (serial 2-fold dilutions in PBS) were added to $100 \mathrm{ml}$ of $\mathrm{hRBC}$ suspension $[4 \%$ $(\mathrm{v} / \mathrm{v})$ in final] in PBS to a final volume of $200 \mu \mathrm{L}$, and incubated for $1 \mathrm{~h}$ at $37^{\circ} \mathrm{C}$. Samples were centrifuged at $1000 \times \mathrm{g}$ for $5 \mathrm{~min}$, and hemoglobin release monitored by measuring supernatant absorbance at $405 \mathrm{~nm}$ with Microplate ELISA Reader. $\mathrm{HC}_{50}$ is defined as the peptide concentration that causes $50 \%$ hemolysis. As negative and positive controls, $\mathrm{hRBCs}$ in PBS ( $\left.\mathrm{A}_{\text {blank }}\right)$ and $0.1 \%$ Triton X-100 ( $\left.\mathrm{A}_{\text {triton }}\right)$ were employed, respectively. The hemolysis percentage was calculated according to the equation:

$$
\% \text { hemolysis }=100 \times\left[\left(\mathrm{A}_{\text {sample }}-\mathrm{A}_{\text {blank }}\right) /\left(\mathrm{A}_{\text {triton }}-\mathrm{A}_{\text {blank }}\right)\right]
$$

Dye leakage. Calcein-entrapped LUVs (large unilamellar vesicles) composed of PE/PG (7:3, w/w) were prepared by vortexing the dried lipid in dye buffer solution $(70 \mathrm{mM}$ calcein, $10 \mathrm{mM}$ Tris, $150 \mathrm{mM} \mathrm{NaCl}, 0.1 \mathrm{mM}$ EDTA, $\mathrm{pH} 7.4)$. The sus- pension was subjected to 10 frozen-thaw cycles in liquid nitrogen and extruded 21 times through polycarbonate filters (two stacked $100-n m$ pore size filters) with a LiposoFast extruder (Avestin, Inc. Canada). Untrapped calcein was removed by gel filtration on a Sephadex G-50 column. The concentration of calcein-entrapped LUVs was determined in triplicate by phosphorus analysis. ${ }^{30}$ Calcein leakage from LUVs was monitored at room temperature by measuring fluorescence intensity at an excitation wavelength of $490 \mathrm{~nm}$ and emission wavelength of $520 \mathrm{~nm}$ on a model RF-5301PC spectrophotometer. Complete dye release was obtained by using $0.1 \%$ Triton X-100. The percentage of dye leakage caused by the peptides was calculated as follows:

$$
\% \text { dye leakage }=100 \times\left[\left(F-F_{0}\right) /\left(F_{\mathrm{t}}-F_{0}\right)\right]
$$

where $F$ is the fluorescence intensity achieved at 3 min after peptide addition, and $F_{0}$ and $F_{\mathrm{t}}$ represent fluorescence intensities without the peptides and with Triton X-100, respectively.

Stability to tryptic digestion. Bacteria (E. coli and $S$. aureus) were grown overnight for $18 \mathrm{~h}$ at $37^{\circ} \mathrm{C}$ in $10 \mathrm{~mL}$ of LB broth and then $10 \mu \mathrm{L}$ of this culture was inoculated into $10 \mathrm{ml}$ of fresh $\mathrm{LB}$ and incubated for an additional $3 \mathrm{~h}$ at $37{ }^{\circ} \mathrm{C}$ to obtain midlogarithmic phase organisms. Digestion of each peptide by trypsin was carried out using $50 \mu \mathrm{g} / \mathrm{mL}$ peptide and $0.2 \mu \mathrm{g} / \mathrm{mL}$ trypsin in $50 \mathrm{mM}$ Tris-HCl buffer, $\mathrm{pH} 7.5$ at $37^{\circ} \mathrm{C}$ for $1 \mathrm{~h}$. The reaction solution $(50 \mu \mathrm{L})$ was added to $150 \mu \mathrm{L}$ of a bacterial suspension $\left(2 \times 10^{6} \mathrm{CFU} / \mathrm{mL}\right.$ in $1 \%$ peptone $)$. After incubation at $37{ }^{\circ} \mathrm{C}$ for $18-20 \mathrm{~h}$, the bacterial growth inhibition was determined by measuring absorbance at $600 \mathrm{~nm}$ with a Microplate autoreader EL 800 (Bio-Tek Instruments).

\section{Results and Discussion}

$\mathrm{K}_{6} \mathrm{~L}_{2} \mathrm{~W}_{3}$ and its peptoid $\mathrm{k}_{6} \mathrm{l}_{2} \mathrm{~W}_{3}$ exhibited a similar antimicrobial activity with MIC ranging between $2 \mu \mathrm{M}$ to $8 \mu \mathrm{M}$ (Table 2). In the hemolytic activity, peptide/peptoid did not induce any hemolysis even at the high concentration of $800 \mu \mathrm{M}$ (Table 2). To determine bacterial selectivity of the peptides, we calculated their therapeutic index (TI) as a measure of the relative safety of the drug. ${ }^{31-33}$ The TI of the peptides was calculated as the ratio of the $\mathrm{HC}_{50}$ that produced $50 \%$ hemolysis against human red blood cells to the average MIC value against six selected microorganisms. Larger values of TI correspond to greater bacterial selectivity. As shown in Table 2, the peptoid $\mathrm{k}_{6} \mathrm{l}_{2} \mathrm{~W}_{3}$ had similar bacterial selectivity compared to the peptide $\mathrm{K}_{6} \mathrm{~L}_{2} \mathrm{~W}_{3}$.

Next, we investigated the kinetics of antimicrobial activity

\begin{tabular}{|c|c|c|c|c|c|c|c|c|c|}
\hline \multirow{2}{*}{ Peptides } & \multicolumn{6}{|c|}{$\operatorname{MIC}^{a}(\mu \mathrm{M})$} & \multirow{2}{*}{$\begin{array}{l}\text { Average } \\
\text { MIC }^{b} \\
(\mu \mathrm{M})\end{array}$} & \multirow{2}{*}{$\begin{array}{l}\mathrm{HC}_{50} \\
(\mu \mathrm{M})^{c}\end{array}$} & \multirow{2}{*}{$\begin{array}{c}\text { Therapeutic } \\
\text { Index (TI) }{ }^{d} \\
\mathrm{HC}_{50} / \text { average MIC }\end{array}$} \\
\hline & E. coli & P. aeruginosa & S. typhimurium & B. subtilis & S. epidermidis & S. aureus & & & \\
\hline $\mathrm{K}_{6} \mathrm{~L}_{2} \mathrm{~W}_{3}$ & 4 & 8 & 2 & 2 & 4 & 4 & 4 & $800<$ & $200<$ \\
\hline $\mathrm{k}_{6} \mathrm{l}_{2} \mathrm{~W}_{3}$ & 4 & 8 & 4 & 2 & 4 & 8 & 5 & $800<$ & $160<$ \\
\hline
\end{tabular}

Table 2. Antimicrobial and hemolytic activities and bacterial selectivity of a Trp-rich model antimicrobial peptide and peptoid

${ }^{a} \mathrm{MIC}(\mu \mathrm{M})$ is defined as the lowest peptide concentration that caused $100 \%$ inhibition of microbial growth. ${ }^{b}$ The average MIC (minimal inhibitory concentration) value from six bacterial strains. ${ }^{c} \mathrm{HC}_{50}$ displays the peptide concentration that causes $50 \%$ hemolysis. ${ }^{d} \mathrm{The}$ therapeutic index (TI) is defined as the ratio $\mathrm{HC}_{50}$ /average MIC. 

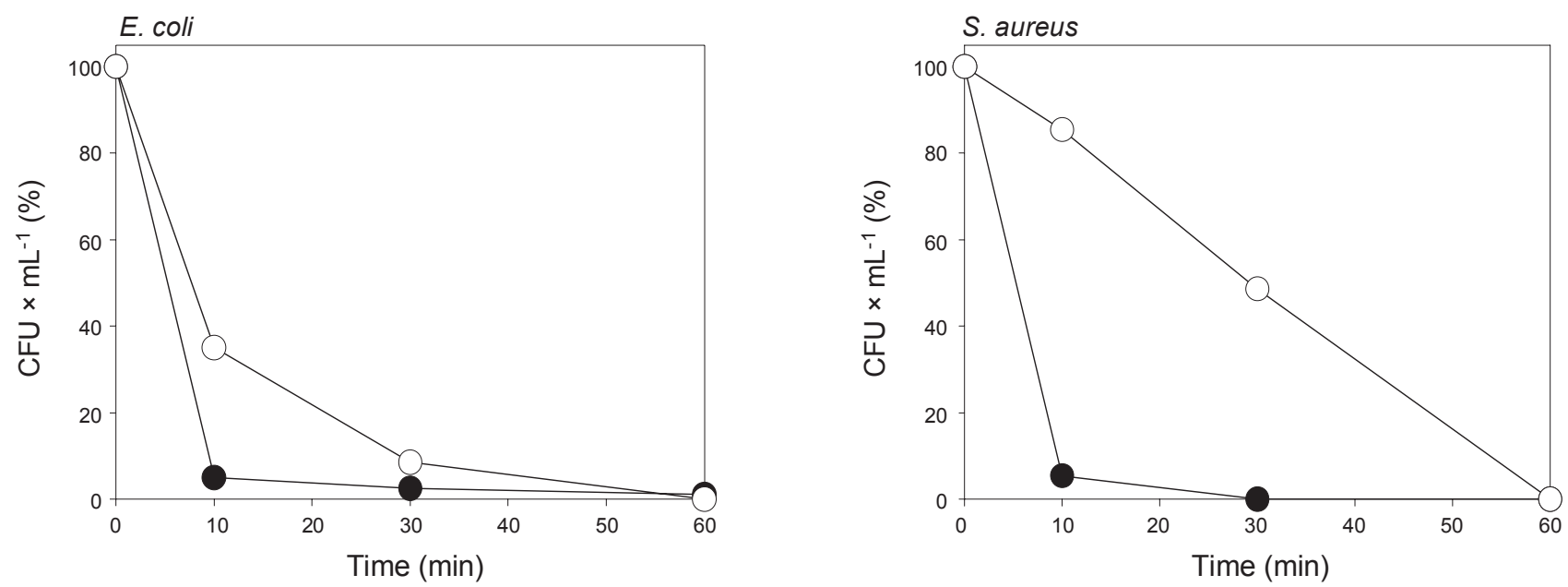

Figure 3. Kinetics of killing of the peptides against Gram-negative E. coli and Gram-positive S. aureus. Bacteria were incubated in the presence of $\mathrm{K}_{6} \mathrm{~L}_{2} \mathrm{~W}_{3}(\bullet)$ or $\mathrm{k}_{6} \mathrm{l}_{2} \mathrm{~W}_{3}(\circ)$ in agar broth. The concentration of each peptide used was $8 \mu \mathrm{M}(1$ or $2 \times \mathrm{MIC})$.

(a)

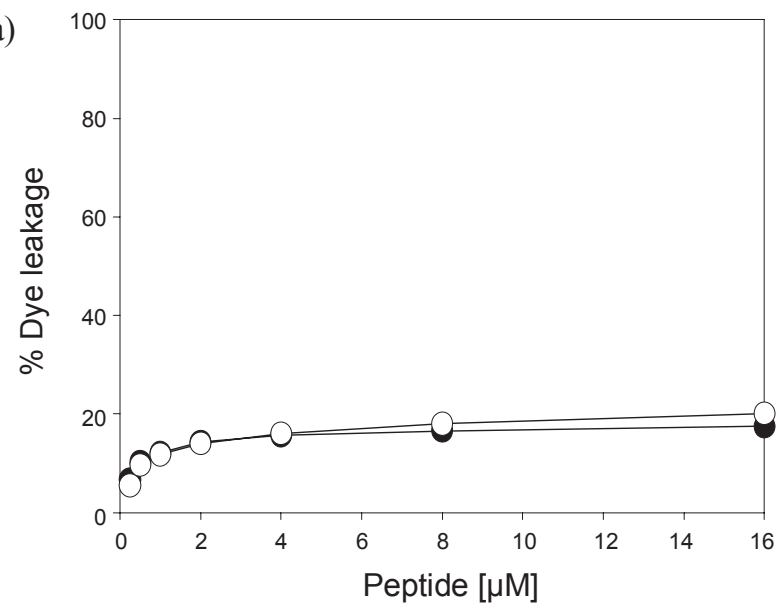

(b)

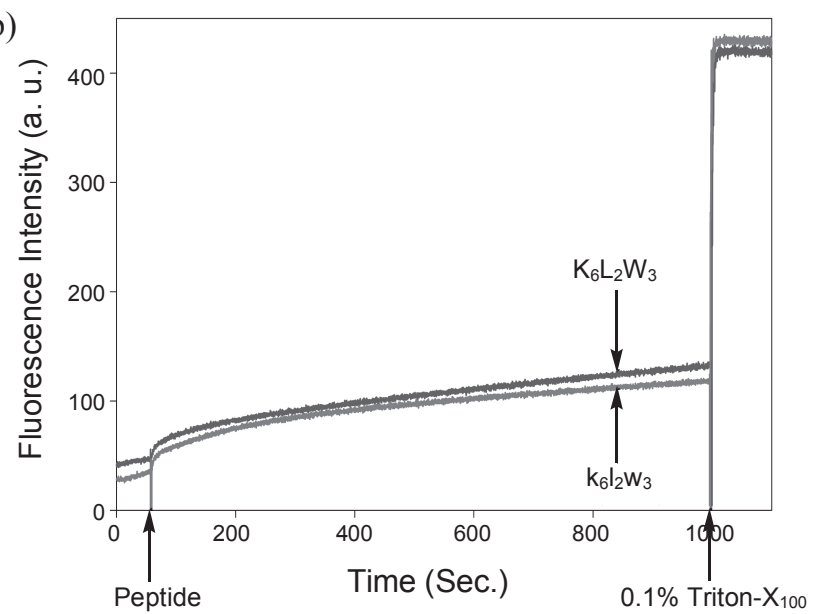

Figure 4. (a) Concentration-dependent dye leakage from calcein-entrapped negatively charged PE/PG (7:3, w/w) LUVs. (b) Time-dependent dye leakage from calcein-entrapped negatively charged PE/PG $(7: 3, \mathrm{w} / \mathrm{w})$ LUVs. Peptide/lipid molar ratio is 0.1 .
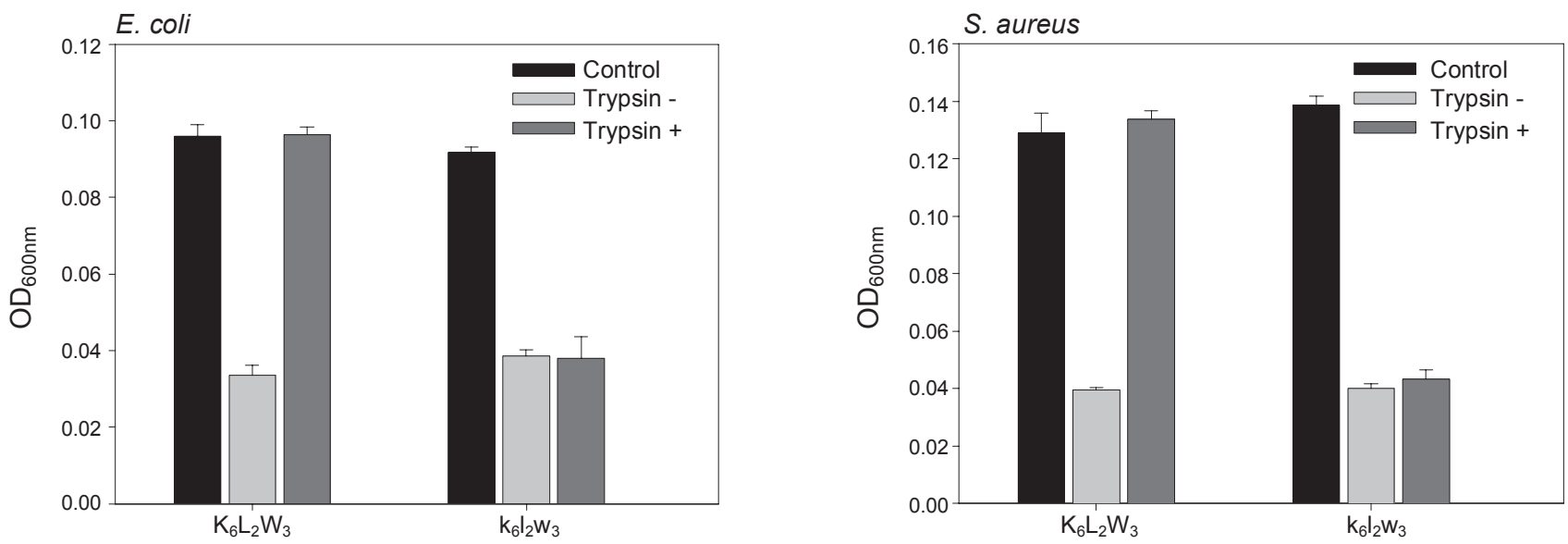

Figure 5. Inhibition of antimicrobial activity of the peptides by trypsin assessed by the broth microdilution assay.

to compare the rate at which these two peptides kill gramnegative Escherichia coli and gram-positive Staphylococcus aureus. We compared the killing kinetics of $\mathrm{K}_{6} \mathrm{~L}_{2} \mathrm{~W}_{3}$ and $\mathrm{k}_{6} \mathrm{l}_{2} \mathrm{~W}_{3}$ against $E$. coli and $S$. aureus at intervals of $0 \mathrm{~min}, 10 \mathrm{~min}, 30 \mathrm{~min}$, and 60 min at the concentration of $8 \mu \mathrm{M}(1$ or $2 \times \mathrm{MIC})$. As shown in Figure $3, \mathrm{~K}_{6} \mathrm{~L}_{2} \mathrm{~W}_{3}$ and $\mathrm{k}_{6} \mathrm{l}_{2} \mathrm{~W}_{3}$ killed nearly E. coli and S. aureus within $10 \mathrm{~min}$ and 30 or $60 \mathrm{~min}$, respectively, suggesting the bactericidal rate of $\mathrm{k}_{6} \mathrm{l}_{2} \mathrm{~W}_{3}$ is somewhat slower than that 
of $\mathrm{K}_{6} \mathrm{~L}_{2} \mathrm{~W}_{3}$. In our previous study, $\mathrm{K}_{6} \mathrm{~L}_{2} \mathrm{~W}_{3}$ displayed very little dye leakage from PE/PG (7:3, w/w) liposomes which mimics the outer membrane of bacteria. ${ }^{14}$ Furthermore, $\mathrm{K}_{6} \mathrm{~L}_{2} \mathrm{~W}_{3}$ penetrated the cell membrane and accumulated in the cytoplasm of $E$. coli and bind strongly to DNA. ${ }^{14}$ As observed in $\mathrm{K}_{6} \mathrm{~L}_{2} \mathrm{~W}_{3}$, the peptoid, $\mathrm{k}_{6} \mathrm{l}_{2} \mathrm{~W}_{3}$ exhibited less dye leakage from PE/PG liposomes (Figure 4). These results indicated that the major target site of $\mathrm{K}_{6} \mathrm{~L}_{2} \mathrm{~W}_{3}$ and $\mathrm{k}_{6} \mathrm{l}_{2} \mathrm{~W}_{3}$ may be not the cell membrane but the cytoplasm of bacteria.

A major limitation to the development of cationic antimicrobial peptide as human therapeutics is their inactivation by endogenous proteases. ${ }^{15-18}$ Poor protease stability severely limits the clinical use of many therapeutic peptides. ${ }^{34,35}$ Of great concern are trypsin-like proteases that abound in the body and are selective for basic residues. Trypsin specifically catalyzes the hydrolysis of C-terminal amide bonds of lysine and arginine, making it an ideal tool in the present study, since the peptides possess six Lys residues. For this reason, the stability of the peptides toward tryptic digestion was examined. The peptides were pretreated with trypsin and their residual antimicrobial activity was assayed by the broth microdilution assay. As shown in Figure 5, trypsin treatment of $\mathrm{K}_{6} \mathrm{~L}_{2} \mathrm{~W}_{3}$ completely abolished antimicrobial activities against $E$. coli and $S$. aureus. In contrast, the antimicrobial activity of $\mathrm{k}_{6} \mathrm{l}_{2} \mathrm{~W}_{3}$ was completely preserved after trypsin treatment.

\section{Conclusion}

In summary, we successfully developed a novel antimicrobial peptoid, $\mathrm{k}_{6} \mathrm{l}_{2} \mathrm{~W}_{3}$ with increased protease stability, as well as good bacterial selectivity. Therefore, the peptoid, $\mathrm{k}_{6} \mathrm{l}_{2} \mathrm{~W}_{3}$ can potentially serves as a promising therapeutic agent for the treatment of microbial infection.

\section{References}

1. Boman, H. G. Annu. Rev. Immunol. 1995, 13, 61.

2. Zasloff, M. Nature 2002, 415, 389.

3. Selsted, M. E.; Ouellette, A. J. Nat. Immunol. 2005, 6, 551.

4. Hancock, R. E.; Brown, K. L.; Mookherjee, N. Immunobiology 2006, 211, 315.

5. Shai, Y. Biopolymers 2002, 66, 236.

6. Epand, R. M.; Vogel, H. J. Biochim. Biophys. Acta 1999, 1462, 11.

7. Chan, D. I.; Prenner, E. J.; Vogel, H. J. Biochim. Biophys. Acta 2006, $1758,1184$.

8. Schibli, D. J.; Epand, R. F.; Vogel, H. J.; Epand, R. M. Biochem. Cell Biol. 2002, 80, 667.
9. Yang, S. T.; Shin, S. Y.; Lee, C. W.; Kim, Y. C.; Hahm, K. S.; Kim, J. I. FEBS Lett. 2003, 540, 229.

10. Yang, S. T.; Shin, S. Y.; Kim, Y. C.; Kim, Y.; Hahm, K. S.; Kim, J. I. Biochem. Biophys. Res. Commun. 2002, 296, 1044.

11. Selsted, M. E.; Novotny, M. J.; Morris, W. L.; Tang, Y. Q.; Smith, W.; Cullor, J. S. J. Biol. Chem. 1992, 267, 4292.

12. Ryge, T. S.; Doisy, X.; Ifrah, D.; Olsen, J. E.; Hansen, P. R. J. Pept. Res. 2004, 64, 171.

13. Rozek, A.; Powers, J. P.; Friedrich, C. L.; Hancock, R. E. Biochemistry 2003, 42, 14130.

14. Park, K. H.; Nan, Y. H.; Park, Y.; Kim, J. I.; Park, I. S.; Hahm, K. S.; Kim, Y.; Shin, S. Y. Biochim. Biophys. Acta 2009, 1788, 1193.

15. Hamamoto, K.; Kida, Y.; Zhang, Y.; Shimizu, T.; Kuwano, K. Microbiol. Immunol. 2002, 46, 741.

16. Svenson, J.; Stensen, W.; Brandsdal, B. O.; Haug, B. E.; Monrad, J.; Svendsen, J. S. Biochemistry 2008, 47, 3777.

17. Meng, H.; Kumar, K. J. Am. Chem. Soc. 2007, 129,15615.

18. Porter, E. A.; Weisblum, B.; Gellman, S. H. J. Am. Chem. Soc. 2002, 124, 7324

19. Wu, C. W.; Sanborn, T. J.; Zuckermann, R. N.; Barron, A. E. J. Am. Chem. Soc. 2001, 123, 2958.

20. Ng, S.; Goodson, B.; Ehrhardt, A.; Moos, W. H.; Siani, M.; Winter, J. Bioorg. Med. Chem. 1999, 7, 1781.

21. Wender, P. A.; Mitchell, D. J.; Pattabiraman, K.; Pelkey, E. T.; Steinman, L.; Rothbard, J. B. Proc. Natl. Acad. Sci. USA. 2000, 97, 13003.

22. Goodman, M.; Bhumralkar, M.; Jefferson, E. A.; Kwak, J.; Locardi, E. Biopolymers 1998, 47, 127.

23. Merrifield, R. B. J. Am. Chem. Soc.1963, 85, 2149.

24. Fields, G. B.; Noble, R. L. Int. J. Pept. Protein Res. 1990, 35, 161.

25. Figliozzi, G. M.; Goldsmith, R.; Ng, S. C.; Banville, S. C.; Zuckermann, R. N. Methods Enzymol. 1996, 267, 437.

26. Zhu, W. L.; Lan, H.; Park, Y.; Yang, S. T.; Kim, J. I.; Park, I. S.; You, H. J.; Lee, J. S.; Park, Y. S.; Kim, Y.; Hahm, K. S.; Shin, S. Y. Biochemistry 2006, 45, 13007.

27. Zhu, W. L.; Song, Y. M.; Park, Y.; Park, K. H.; Yang, S. T.; Kim, J. I.; Park, I. S.; Hahm, K. S.; Shin, S. Y. Biochim Biophys Acta 2007, 1768, 1506.

28. Lee, J. U.; Park, K. H.; Lee, J. Y.; Kim, J.; Shin, S. Y.; Park, Y.; Hahm, K. S.; Kim, Y. Bull. Korean Chem. Soc. 2008, 26, 1190.

29. Park, K.; Shin, S. Y.; Hahm, K. S.; Kim Y. Bull. Korean Chem. Soc. 2003, 24, 1478.

30. Barlett, C. R. J. Biol. Chem. 1959, 234, 466.

31. Hancock, R. E.; Scott, M. G. Proc. Natl. Acad. Sci. USA 2000, 97 , 8856.

32. Fazio, M. A.; Jouvensal, L.; Vovelle, F.; Bulet, P.; Miranda, M. T.; Daffre, S.; Miranda, A. Biopolymers 2007, 88, 386.

33. Solanas, C.; de la Torre B. G.; Fernández-Reyes, M.; Santiveri, C. M.; Jiménez, M. A.; Rivas, L.; Jiménez, A. I.; Andreu, D.; Cativiela, C. J. Med. Chem. 2009, 52, 664.

34. Latham, P. W. Nat. Biotechnol. 1999, 17, 755.

35. Sato, A. K.; Viswanathan, M.; Kent, R. B.; Wood, C. R. Curr. Opin. Biotechnol. 2006, 17, 638. 